\title{
Evaluating firm profitability during the servitization process of the music industry
}

\author{
Vasileios Myrthianos \\ Management department, University of Granada \\ vasileios.myrthianos@upc.edu \\ Ferran Vendrell-Herrero \\ Birmingham Business School, University of Birmingham \\ f.vendrell-herrero@bham.ac.uk \\ Glenn Parry \\ Bristol Business School, University of the West of England \\ Glenn.parry@uwe.ac.uk \\ Oscar F. Bustinza \\ Management Department, University of Granada \\ oscarfb@ugr.es
}

\section{Biographical Notes}

Vasileios Myrthianos, Ph.D. (University of Granada) is an assistant professor in the Polytechnic University of Barcelona. He has extensive experience of working as an associate researcher and assistant professor at the Autonomous University of Barcelona and Open University of Catalonia. His current research interests include strategy, operation management and the music industry. 
Ferran Vendrell-Herrero, Ph.D. (Universitat Autonoma de Barcelona) is a lecturer in managerial economics in the University of Birmingham, UK. His research interests focused on assessment of innovation policies for SMEs and the servitization process in creative industries. Dr. Vendrell-Herrero's research has been published in the International Journal of Production Economics, Technovation, Small Business Economics, Regional Studies and Supply Chain Management among other outlets.

Glenn C Parry, Ph.D. (Cantab) is an Associate Professor of Strategy and Operations Management at the University of the West of England, UK. His work aims to capture leading practice, moving companies forward through transformations based upon data driven analysis. Dr Parry has been published in numerous international journals and has published the books, "Build to Order: The Road to the 5-day Car", "Complex Engineering Service Systems" and "Service Design and Delivery" which was ranked in the IIJ top 20 upcoming design books for innovators.

Oscar F. Bustinza, Ph.D. (University of Granada) is an Associate Professor of strategy and operations management at the University of Granada, Spain. His work aims to capture successful business practices, analyzing drivers of firm's boundaries choice and the leveraging of supplier, customer or inter-firm relationships based upon data driven analysis. Dr. Bustinza's research has been published in the International Journal of Operations and Production Management, International Journal of Production Economics, Journal of Supply Chain Management, International Journal of Production Research, and British Journal of Management among other outlets. 


\section{Acknowledgements:}

Ferran Vendrell-Herrero acknowledges financial support from ECO 2010-21393-C04 and the support provided by Birmingham Business School. Oscar F. Bustinza acknowledges financial support from ECO2010- 16814. Dr Parry acknowledges the support provided by Bristol Business School, UWE.

\section{One sentence summary:}

Music industry revenues are highly correlated with firm profitability, which after the digital disruption on average is below the risk-free bank interest rate.

\section{Summary:}

The music industry, as with other creative industries, has suffered a dramatic decrease in performance due to the digital disruption.

While previous literature uses revenues as a proxy for performance, this paper uses profits, confirming the link between the fall in industry revenues and firm profits.

Profits have decreased more for local firms than multinationals indicating that the large firms adapt better to technological and economic disruptions.

Keywords: Servititization, technological disruption, economic disruption, music industry, firm profits.

J.E.L Codes: L1 


\section{Introduction}

Servitization was defined by Vandermerwe and Rada (1998) as an increment of the entire market package of customer focused combinations of products, services and knowledge offered by a firm searching for additional value from their base product offerings. An increased service offer gives manufacturers the opportunity to gather more data on their customer's use of their offering (Neely, 2008). Business models related to servitization are used to develop the firm's innovation capabilities to create value at the customer-offer level (Visnjic and Van Looy, 2013), which requires a shift in management perspective (Barnett et al., 2013). In the present paper we explore the case of the music industry which has suffered financially following a transition in its offer, from selling music predominantly in product format to a broader offer of product and services (Parry et al., 2012). The servitization process in the music industry is of particular interest given the potential cannibalistic nature of the format offering; very rarely will a consumer purchase the same content in different formats.

The servitization process of the music industry can be catalogued in three different time frames (Vendrell-Herrero et al., 2013a). The first is named Expansion and ranges from 1990 to 1998 . The Expansion time frame is characterized by significant revenue growth based on the success of the product-centric business model selling CDs. According to Alexander (1994) during this period the music industry was dominated by six large multi-divisional firms that accounted for the majority of the global market share. The second period named Technological Disruption is characterized by a dramatic decrease in industry revenue. Technological Disruption began in 1999 (Vaccaro and Cohn, 2004) and revenue decline may be attributed to the appearance of technological disruptions (Christensen and Overdorf, 2000) such as widespread access to broadband internet and the MP3 file format which allowed songs to be digitally 
compressed down to small file sizes which in turn could be easily distributed and stored (Tidd et al., 2005). Further innovations heralded the arrival of P2P networks and the rise of illegal downloading or piracy (Liebowitz, 2006 and 2008). The changing market conditions led to the introduction of new business models (Bustinza et al., 2013a; Spring and Mason, 2011), creating new supply chain linkages (Bustinza et al., 2013b) and giving rise to IPR regulation such as Hadopi (2009) in France and the Digital Economy Act (2010) in the UK. The third period, named Economic Disruption, began in 2008 with the global financial and economic crisis (Reinhart and Rogoff, 2009). According to Hracs (2013) the market share of the big multinationals decreased during the second and third periods of disruption as digital technologies allowed local firms and small intermediaries to compete with multinationals.

This paper analyses the effect of MP3 innovation in the context of the music industry for two consecutive periods. First, the Technological Disruption period where MP3 produced a paradigm shift in the market structure with the beginning of the servitization process. Second, the Economic Disruption period which produced important changes that affected firms competing in the music industry. These two periods are analysed from a financial perspective, exploring the consequences for the industry. The theoretical grounding for the disruptive innovation and servitization concepts are presented below followed by financial analysis, findings and conclusions.

\section{Theoretical framework}

\section{Innovation and servitization}

According to the OCDE (1991) innovation "is an iterative process initiated by the perception of a new market and/or new service opportunity for a technology-based invention which leads to development, production and marketing tasks striving for the 
commercial success of the invention". This definition of innovation includes the introduction of the invention to final consumers in the market through adoption and diffusion (Abernathy and Clark, 1985). Under a similar framework, innovativeness can be viewed as a measure of the degree of newness of an innovation; that is the degree of discontinuity that a product or service can generate in marketing and/or technological processes (Garcia and Calantone, 2002). From a macro point of view, innovation is the potential to produce a paradigm change to a new technological state and/or market structure in an industry (Yoon and Lilien, 1985). At a micro level, innovativeness is defined as new to firm and/or customer (More, 1982).

MP3 technology appeared in the early 1990s but established music companies did not embrace this technology (Tidd et al., 2005). MP3 innovativeness, from a macro point of view, caused a complete technological and market industry change that was not rapidly assimilated by the incumbent industry members. The reasons for the lack of reaction by incumbents may be traced to the music companies having capital invested in production and marketing processes which focused on a different technology (Tschmuck, 2012). If the established technology became obsolete the sunk costs of investment would have to be considered for write-down. The music industry was locked-in; a situation where firms only change technology if high opportunity costs are involved (Antonelli, 1995). However, from a micro point of view MP3 technology led to the servitization of the music industry (Parry et al., 2012). A range of digital services developed to complement the product offering and compete with the rise of illegal file sharing sites. From this perspective, servitization is defined as "the innovation of an organisations capabilities and processes to better create mutual value through a shift from selling product to selling Product-Service Systems" (Baines et al., 2009). In summary, MP3 is a technological innovation that produced a paradigm shift for the 
music industry at the macro level and was an initiator of a servitization process at the micro level.

The main drivers of the servitization process are categorized as financial, strategic and marketing (Oliva and Kallenberg, 2003). Strategic factors are related to searching for competitive advantage through servitization; Marketing factors relate to the customer's central role in this process (Mathieu, 2001); Financial factors relate to firms searching for higher profit margin and recurrent incomes (Neely et al., 2008; Wise and Baumgartner, 1999). Wise and Baumgartner (1999) analysed how firms go downstream to provide services, estimating that margins could be up to twice as high as products. It is the financial drivers of servitization which will form the focus of this paper.

Financial factors are also related to the characteristics of product-service sales which have been shown to be more resilient to the vagaries of economic cycles (Oliva and Kallenberg, 2003). Table 1 presents the decrease in revenues observed in the music industry during the Technological and Economic Disruption periods. The evidence reported is based on previous studies (Bustinza et al., 2013a) and clearly shows that the 10 countries analyzed have negative revenue growth in both periods. Japan and the UK are the countries that suffer least in the Technological Disruption period, losing around $12 \%$ of their revenue volume in 2000 . The Netherlands is the country that suffers the least from the Economic Disruption, with a marginal negative revenue rate of $-0.01 \%$. In contraposition to these cases is Spain, the country where industry suffered the most in both periods, losing $50 \%$ of revenue during the Technological Disruption period and a further $30 \%$ during the economic recession. For this reason this study will focus on firm performance in the Spanish context; the country that experienced the greatest decrease in revenue. 
The evidence reported in this paper comes from secondary sources: the Bureau van Dijk FAME database for global businesses and their SABI database for Spanish businesses. The case of Spain is further developed through multivariate analysis exploiting evidence from unbalanced panel data containing information for 158 observations for 9 firms for the period 1992-2010.

\section{[Insert Table 1]}

This paper contributes to the extant literature by addressing three research questions. First, previous literature on the music industry analyzes performance based on aggregate revenues (Bustinza et al., 2013a; Liebowitz, 2008; Vendrell-Herrero et al., 2013a). This paper makes the analysis at firm level which allows the study of a general variable of firm performance, in this case Return on Assets (ROA), and correlates ROA with firm revenues. Second, the paper analyzes differences in firm performance across two time periods where revenues fell in the music industry. Third, this paper provides an understanding of the differences in performance between multinational and local firms during the Expansion, Technological Disruption and Economic Disruption periods. The following sub-section develops the objectives of the paper and empirical hypotheses.

\section{Hypothesis development}

The main objective of the servitization process is to increment the usage value of the original product, offering a variety of product-service packages in order to satisfy the increasing/changing needs of the consumer (Vandermerwe and Rada, 1998). The servitization process may introduce new business models that require innovation in terms of the offering. Previous music industry research has focused on the analysis of 
industry revenues as a measure of industry performance; a measure that is not necessarily positively correlated with firm profits.

Building on standard microeconomics (Kreps, 1990) firm profit for a single product company can be described with the function $\Pi=(P-C)^{*} Q-C F$, where $P$ equals the price of the good, $Q$ the quantity sold, $C$ the variable cost and $C F$ the fixed cost. Using this terminology, firm revenues equal $P^{*} Q$. A direct implication of this formulation is that firm revenues and firm profits are perfectly correlated when the cost functions are constant over time. Firms that can improve their efficiency, reducing (variable and/or fixed) costs, can achieve a larger profit at fixed revenue - a rational goal for a firm increasing the digital offer.

Previous empirical research indicates that different measures of firm performance such as firm profitability, productivity and survival are positively correlated in the manufacturing and service sectors (Vendrell-Herrero et al., 2013b). Bringing evidence to a framework in the music industry the first empirical hypothesis is derived.

H1: In the music sector, firm revenues are positively linked with firm profits.

As shown in Table 1 the evolution of revenues clearly decreases after the Technological (Tidd et al., 2005) and Economic (Reinhart and Rogoff, 2009) disruption periods (see Vendrell et al.2013a); however there is a no evidence given for the evolution of firm profits during these periods. Using the same rational of the previous hypothesis it may be expected that firm profits will decrease during the Technological and Economic Disruption periods, given that revenues suffered a significant reduction. 
H2a: Firm profits during the Technological Disruption period is lower than firm profits in the Expansion period

H2b: Firm profits during the Economic Disruption period is lower than the firm profits in the Expansion period.

The dynamism of the environment during the Technological and Economic Disruptions effectively broke the supply chain of the industry (Bustinza et al., 2013b) and the relationship between musicians and cultural intermediaries (major multinational labels and small local firms) remains poorly understood (Thompson et al., 2007). For instance, the digitalization of content during the Technological Disruption changed the way music is produced, promoted and distributed; normally presented as an advantage for musicians who are now able to perform a wide range of creative and non-creative tasks individually (Hracs, 2012). According to recent evidence provided by Hracs (2013) this advantage exists but has important limitations. Hracs based his analysis on comprehensive interviews with 65 key agents in the music sector in Ontario (Canada) and concluded that small local intermediaries are more important than ever. Instead of articulating the will of major labels, local intermediaries "perform the more complex and important function of interpreting the marketplace itself and developing specific business strategies for their clients" (p.2). This suggests that local intermediaries adapt more rapidly to the disruptions and leads to the following empirical hypotheses.

H3a: The negative effect of Technological Disruption in firm performance is greater for multinational firms rather than for local firms.

H3b: The negative effect of Economic Disruption in firm performance is greater for multinational firms than for local firms. 


\section{Firm profits in the music industry}

\section{Data construction}

The question of how to measure a firm's profitability over the long term led to a long debate in the literature (Cooper et al. 1994; Storey 1994; Wiklund et al. 2003). At a theoretical level the net present value of all economic profits obtained over a firm's life has been presented as the optimal evaluation of venture performance (Ross, 1995). However, this measure could be difficult to obtain as, for example, the firm's opportunity cost is unobservable and heterogeneous. According to Robinson (1999) Return on Assets (ROA) is an appropriate measure for assessing firms' financial performance because it "indicates management's effectiveness in employing the assets entrusted to them and does not depend on the alternative use of debt versus equity to fund such assets" (p. 169). According to Murphy et al. (1996) most empirical studies use efficiency as a dimension of performance, with ROA the second most used measure for efficiency after ROI. Though not denying the relevance of other measures (i.e., ROE, ROI, ROS), in this paper ROA will be taken to offer a comprehensive criterion, as suggested by Robinson, to compute the profits of local and multinational music firms.

Because profits must be analyzed at the firm and not the industry level, financial information was extracted from the Bureau Van Dijk FAME database for three global and European music multinationals (EMI, SONY, UNIVERSAL) for descriptive purposes and from the Bureau Van Dijk SABI database for the Spanish operations of music multinationals and Spanish local music SMEs. In particular data was available from SABI from the year 1992 to 2011, and data availability from FAME covered the period 2002-2012.

The test of empirical hypotheses requires the construction of a comparable sample of firms. For this reason analysis focuses on the Spanish market only, comparing the 
Spanish operations of music multinationals with a sample of local firms. In particular, analysis uses data from the 3 major multinationals Spanish operations and 6 Spanish SMEs. The empirical design requires that local companies share characteristics with the local operations of the multinationals during the expansion, technological disruption and economic disruption periods, covering the period 1992-2011 with at least one usable observation in each period. To create a comparative sample the control group of local music firms composed of 6 Spanish music SMEs were selected by strictly matching industry and geographical region (Ritter, 1991; Spiess and Affleck-Graves, 1995). All local companies are categorized in the CNAE2009 under code 5920 and headquarters are located in capital cities, as with the multinationals local operation (Florida and Jackson, 2010). The data restrictions make the identification of a larger control group difficult. However, in statistical terms the sample of local SMEs is an appropriate size, as statistical inference and validity requires that treatment and comparison groups are of a similar sample size (Aranguren et al., 2013; Fleiss et al., 2003).

\section{The Global and Spanish business}

Figures 1 reports the evolution of ROA for global business of multinational firms for the period 2002-2012. EMI GLOBAL reports maximum profits in 2003 and SONY EUROPE and UNIVERSAL GLOBAL in 2004. The performance of these firms fell significantly during the Technological and Economic disruptions reaching minimum levels in 2011 for EMI GLOBAL, 2012 for SONY EUROPE and 2009 for Universal GLOBAL. These results confirm the general tendency of a significant decrease in profits. Whilst this is a significant decrease in firm profits the firms are still competitive and able to survive. 
Figure 2 reports the evolution of the Spanish business of multinational firms. All firms report their maximum profits during the Expansion period or at the beginning of the Technological Disruption period, which is consistent with the industry revenues evolution shown in Table 1. In particular, EMI SPAIN reported its maximum profits in 2001 as $29.8 \%$, UNIVERSAL SPAIN in 1998 as 14.2\% and SONY SPAIN in 1998 as 28.3\%. In 2011, these firms' performance was significantly smaller; 3 times smaller for EMI SPAIN, 6 times smaller for SONY SPAIN and negative for UNIVERSAL SPAIN.

[Insert Figure 2]

Figure 3 reports the evolution of ROA for local Spanish music firms. Only Firm 3 achieved a high level of profit (taken to be $10 \%$ and above) consistently during the period analyzed. The other firms are not achieving sustained profits at a level above the risk free bank interest rates. Most achieve a maximum ROA between 1998 and 2002, the period in the transition between Expansion and Technological Disruption. For instance, Firm 5 reached a 42\% ROA in 1997 and a 37\% ROA in 1998. From this moment on the firm achieves marginal or negative profits, the only exception being 2011 when it reaches a $10.4 \%$ ROA. The other firms achieve marginal profits.

[Insert Figure 3]

\section{Corroborating hypotheses: Multivariate analysis of Spanish business}

The evidence provided allows analysis of the evolution of firm performance during the different time frames for the Spanish businesses and a comparison of the performance of the local operation of multinationals and local firms. Using the SABI database a panel for 9 firms is constructed covering the period 1992-2011. Given the nature of financial databases missing data exists for some observations (Garcia-Lara et al., 2006) which make the panel unbalanced. The data contains 158 data points. 
With this database it is possible to test the empirical hypotheses. In order to accomplish this objective the model shown in Equation 1 is estimated.

$$
\begin{gathered}
\operatorname{ROA}_{\mathrm{it}}=\alpha+\beta_{1} \text { LnRevenues }_{\mathrm{it}}+\beta_{2} \text { Tech_disruption }_{\mathrm{t}}+\beta_{3} \text { Econ_disruption }_{\mathrm{t}}+ \\
\beta_{4} \text { Multinational }_{\mathrm{i}}+\varepsilon_{\mathrm{it}}
\end{gathered}
$$

Where the sub-indexes $i$ and $t$ refer to the firm and time respectively. The variable LnRevenues is the logarithm of the revenues deflated by two-digit industry level deflators (Wakelin, 2001). The variables Tech_disruption and Econ_disruption are dummies, taking the value 1 when the firm operates in that period and 0 otherwise. In this category the baseline variable is Expansion. The variable Multinational is a dummy taking the value one when the firm is a multinational and 0 when the firm is a local SME. These variables already control for time and firm unobserved heterogeneity, therefore the methodology combines variables controlling time and firm effects with random effects estimation (Moulton, 1986), which assists in controlling for unobserved heterogeneity without sacrificing degrees of freedom. Table 2 reports the results of the OLS (ordinary least squares) with random effects estimation of Equation 1.

[Insert Table 2]

The first hypothesis analyzes the positive correlation between firm performance and revenues, the most frequently explored variable in previous analysis of the music industry. According to Column 1 of Table 2 LnRevenues is positively linked to ROA; this result is statistically significant at $1 \%$ level. This evidence confirms hypothesis 1 , that in the music sector firm revenues are positively linked with firm profits and adds credibility and robustness to the use of revenues as a measure of industry performance. 
Hypotheses $2 \mathrm{a}$ and $2 \mathrm{~b}$ analyse firm performance across the Technological and Economic Disruptions respectively, in which the servitization of the music industry began to unfold. According to the estimations in the first column of Table 2 the average ROA during the Technological Disruption is $4.15 \%$ smaller than the average ROA during the Expansion period. This result is statistically significant at 5\% which allows Hypothesis 2a to be accepted. Similarly, the average ROA during the Economic Disruption is $6.14 \%$ smaller than the average ROA during the Expansion period. This evidence is significant at $1 \%$ and supports hypothesis $2 \mathrm{~b}$. However, Technological and Economic Disruptions coexist in the last period and therefore the net effect of the Economic Disruption is the difference between both parameters, $-1.99 \%(4.15 \%$ $6.14 \%)$. This difference is not statistically significant which suggests that the decrease of ROA due to the economic crisis alone would not have significantly changed the firm profits of the music industry.

The last objective of this paper is to compare firm profitability between Spanish operations of the multinationals and local firms. According to the estimation of the first column in Table 2 the ROA of the multinational operation of Spanish businesses is on average $-1.35 \%$ smaller than the average ROA of local firms; however this result is not statistically significant. Hypotheses $3 \mathrm{a}$ and $3 \mathrm{~b}$ analyse if there are different patterns in the evolution of firm profits between both groups. Based on the work of Hracs (2013) there is an expectation of greater profits for local firms during the Technological and Economic Disruptions. In order to contrast these hypotheses we incorporate interaction terms with Technological and Economic Disruption variables in the second column of Table 2. The coefficient of the interaction terms are positive, which indicates that, contrary to what was hypothesised, in the Spanish context the multinationals operations adapt better to disruptions than local firms. For example, we find that in Spain music 
multinationals achieve on average a ROA $7.43 \%$ greater than SMEs during the Technological Disruption period; this result is significant at 5\% level. This evidence is not consistent with the work of Hracs (2013), which expects local firms to adapt better than multinationals local operations during the Technological Disruption period.

\section{Conclusions}

The music industry has suffered disruptions which have had a negative impact on firm revenues (Bustinza et al., 2013a). The managers of the industry adapted (Barnett et al., 2013) and introduced new business models (Spring and Mason, 2011) related to the introduction of digital products and service in their offerings, which have been defined as the servitization process of the music industry (Parry et al., 2012). Previous literature analyzed this process at industry level with revenues as the only measure of performance (Bustinza et al., 2013a; Liebowitz, 2008; Vendrell-Herrero et al., 2013). We complemented this analysis offering information at firm level and measuring firm performance through a comprehensive measure of profits, taking Return on Assets as the metric (Robinson, 1999). Our analysis suggests that firm profits have decreased during Technological and Economic Disruptions. According to the data available the average ROA ranged from 10\% during the Expansion period (1992-1998), moving down to 4-5\% during the Technological Disruption period (1999-2007) and 2-3\% during the Economic Disruption period (2008-2011).

New business model implementation as a result of the efforts of the industry to adapt to new market conditions allows incumbent firms to survive, though with marginal profitability which in some cases provides returns below the banking risk free interest rates. This has implications for future research, particularly the research agenda analyzing in-depth the value and composition of new intangible (i.e. digital, streaming) 
business models as well as the impacts of piracy on the potential revenue of such firms. This paper also contributes to the literature comparing the capacity of local firms to compete with multinationals during the digital era. Our findings contradict the current lines of research suggesting that local firms and intermediaries can adapt better to the new conditions of the music industry (Hracs, 2013), highlighting that the multinationals in national markets are achieving greater performance during the Technological Disruption than local firms.

Our empirical evaluation of the music industry collects exhaustive information of the dynamism of the industry and uses as a performance variable return on assets (ROA); however we acknowledge some limitations. For instance, our evidence focusses on a particular context, Spain, and data is drawn from a small sample of firms which can suffer from sample selection bias. Our methodology required the construction of a sample of Spanish SMEs and multinational cohorts, which experienced all the stages in the music industry during the last 20 years. Therefore, our evidence remains silent on firm demographics in creative industries. New firms could be more successful in exploiting new business models, as described by Hracs (2013). Future research will need to expand the number of samples and contexts to correct for these biases. Further, this paper is silent on the direct impact of piracy in isolation to other factors; piracy is particularly significant in the Spanish market (Bustinza et al., 2013a). 


\section{References}

Abernathy WJ, Clark KB. 1985. Innovation: mapping the winds of creative destruction. Research Policy 14(1): 3-22.

Alexander PJ. 1994. New technology and market structure: evidence from the music recording industry. Journal of Cultural Economics 18(2): 113-123.

Antonelli C. 1995. The Economics of Localized Technological Change and Industrial Dynamics. Springer Berlin: Heidelberg.Baines TS, Lightfoot HW, Benedettini O, Kay JM. 2009. The servitization of manufacturing: a review of literature and reflection on future challenges. Journal of Manufacturing Technology Management 20(5): 547-567.

Aranguren, M., de la Maza, X., Davide Parrilli, M., Vendrell-Herrero, F., \& Wilson, J. R. 2013. Nested Methodological Approaches for cluster policy evaluation: An application to the Basque country. Regional Studies. DOI: $10.1080 / 00343404.2012 .750423$

Barnett NJ, Parry G, Saad M, Newnes LB, Goh YM. 2013. Servitization: is a paradigm shift in the business model and service enterprise required?. Strategic Change 22(3-4): 145-156.

Bustinza OF, Vendrell-Herrero F, Parry G, Myrthianos V. 2013a. Music business models and piracy. Industrial Management \& Data Systems 113(1): 4-22.

Bustinza OF, Parry G, Vendrell-Herrero F. 2013b. Supply and demand chain management: the effect of adding services to product offerings. Supply Chain Management: An International Journal 18(6): .

Christensen CM, Overdorf M. 2000. Meeting the challenge of disruptive change. Harvard Business Review 78(2): 66-77. 
Cooper AC, Gimeno-Gascon FJ, Woo CY. 1994. Initial human and financial capital as predictors of new venture performance. Journal of Business Venturing 9(5): 371395.

Digital Economy Act. 2010. Chapter 24. Available at: www.legislation.gov.uk [4 November 2012].

Fleiss, J. L., Levin, B., \& Paik, M. C. 2003. Regression models for matched samples. Statistical Methods for Rates and Proportions, Third Edition, 407-439.

Florida R, Jackson S. 2010. Sonic city: the evolving economic geography of the music industry. Journal of Planning Education and Research 29(3): 310-321.

Garcia R, Calantone R. 2002. A critical look at technological innovation typology and innovativeness terminology: a literature review. Journal of product innovation management 19(2): 110-1132.

Hadopi (2009). LOI n 2009-669 du 12 juin 2009 favorisant la diffusion et la protection de la création sur internet. Available at: www.legifrance.gouv.fr [5 April 2012].

Hracs BJ. 2012. A creative industry in transition: the rise of digitally driven independent music production. Growth and Change 43(3): 442-461.

Hracs BJ. 2013. Cultural intermediaries in the digital age: the case of independent musicians and managers in Toronto. Regional Studies Forthcoming.

Kreps, D. M. 1990. A course in microeconomic theory (Vol. 41). Princeton: Princeton University Press.

Lara JMG, Osma BG, Noguer BGDA. 2006. Effects of database choice on international accounting research. Abacus 42(3-4): 426-454.

Liebowitz, S. J. 2006. File Sharing: Creative Destruction or Just Plain Destruction?*. Journal of Law and Economics, 49(1), 1-28. 
Liebowitz, S. J. 2008. Research Note-Testing File Sharing's Impact on Music Album Sales in Cities. Management Science, 54(4), 852-859.Mathieu V. 2001. Product services: from a service supporting the product to service supporting the client. Journal of Business \& Industrial Marketing 16(1): 39-58.

More RA. 1982. Risk factors in accepted and rejected new industrial products. Industrial Marketing Management 11(1):9-15.

Moulton BR. 1986. Random group effects and the precision of regression estimates. Journal of econometrics 32(3): 385-397.

Murphy, G. B., Trailer, J. W., \& Hill, R. C. 1996. Measuring performance in entrepreneurship research. Journal of business research, 36(1), 15-23.

Neely A. 2008. Exploring the financial consequences of the servitization of manufacturing. Operations Management Research 1(2): 103-118.

OECD. 1991. The nature of innovation and the evolution of the productive system technology and productivity-the challenge for economic policy (pp. 303-314). OECD: Paris.

Oliva R, Kallenberg R. 2003. Managing the transition from products to services. International Journal of Service Industry Management 14(2): 160-172.

Parry G, Bustinza OF, Vendrell-Herrero F. 2012. Servitisation and value co-production in the UK music industry: an empirical study of consumer attitudes. International Journal of Production Economics 135(1): 320-332.

Reinhart CM, Rogoff KS. 2009. The Aftermath of Financial Crises (No. w14656). National Bureau of Economic Research: New York.

Ritter, J. R. 1991. The long-run performance of initial public offerings. The journal of finance 46(1), 3-27. 
Robinson KC. 1999. An examination of the influence of industry structure on eight alternative measures of new venture performance for high potential independent new ventures. Journal of Business Venturing 14(2): 165-187.

Ross, S. A. 1995. Uses, abuses, and alternatives to the net-present-value rule. Financial management 24(3): 96-102.

Spiess, D. K., \& Affleck-Graves, J. 1995. Underperformance in long-run stock returns following seasoned equity offerings. Journal of Financial Economics, 38(3), 243267.

Storey DJ. 1994. The role of legal status in influencing bank financing and new firm growth. Applied Economics 26(2): 129-136.

Thompson P, Jones M, Warhurst C. 2007. From conception to consumption: creativity and the missing managerial link. Journal of Organizational Behavior 28(5): 625640.

Tidd J, Bessant J. 2005. Managing Innovation: Integrating Technological, Market and Organizational Change. Wiley: New York.

Tschmuck P. 2012. Creativity and Innovation in the Music Industry (pp. 225-251). Springer Berlin: Heidelberg.

Vaccaro VL, Cohn DY. 2004. The evolution of business models and marketing strategies in the music industry. International Journal on Media Management 6(12): $46-58$.

Vandermerwe S, Rada J. 1988. Servitization of business: adding value by adding services. European Management Journal 6(4): 314-324.

Vendrell-Herrero F, Parry G, Bustinza OF, O’Reagan N. 2013a. New Digital Markets: New Business Models. Presented at Academy of Management Annual Meeting. Orlando. 
Vendrell-Herrero F, González-Pernía JL, Peña-Legazkue I. 2013b. Do incentive matter to promote high technology-driven entrepreneurial activity?, International Entrepreneurship and Management Journal. DOI: 10.1007/s11365-011-0181-4

Visnjic I, Van Looy B. 2013. Servitization: disentangling the impact of service business model innovation on manufacturing firm performance. Journal of Operations Management. Forthcoming.

Wakelin K. 2001. Productivity growth and R\&D expenditure in UK manufacturing firms. Research policy 30(7): 1079-1090.

Wiklund J, Davidsson P, Delmar F. 2003. What do they think and feel about growth? An expectancy-value approach to small business managers' attitudes toward growth. Entrepreneurship Theory and Practice 27(3): 247-270.

Wise R, Baumgartner P. 1999. Go downstream. Harvard Business Review, 77(5): 133141.

Yoon E, Lilien GL. 1985. New industrial product performance: the effect of market characteristics and strategy. Journal of Product Innovation Management 2(3):13444. 
Table 1. The evolution of music industry revenues during the Technological and Economic Disruption

\section{Average Revenue Growth}

\begin{tabular}{lcc}
\hline Country & $\begin{array}{c}\text { Technological } \\
\text { Disruption }\end{array}$ & Economic \\
\hline Dustralia & $-19.00 \%$ & $-8.63 \%$ \\
Canada & $-34.65 \%$ & $-18.30 \%$ \\
France & $-30.32 \%$ & $-7.38 \%$ \\
Germany & $-34.06 \%$ & $-6.89 \%$ \\
Italy & $-35.51 \%$ & $-19.09 \%$ \\
Japan & $-12.06 \%$ & $-18.22 \%$ \\
Netherlands & $-27.21 \%$ & $-0.01 \%$ \\
Spain & $-50.72 \%$ & $-32.31 \%$ \\
United Kingdom & $-12.53 \%$ & $-9.33 \%$ \\
United States & $-26.58 \%$ & $-19.68 \%$ \\
\hline
\end{tabular}

Source: Self elaborated from data provided by IFPI. The data is the same as the exploited in Bustinza et al. (2013a). Given this limitation the Technological Disruption is measured during the period 2000-2007 and the Economic Disruption during the period 2008-2010. 
Table 2. OLS with random effects analyzing the causes of firm performance

\begin{tabular}{|c|c|c|}
\hline Independent Variable: ROA & Model 1 & Model 2 \\
\hline \multirow[t]{2}{*}{ Ln(Revenues) } & $3.70 * * *$ & $4.04 * * *$ \\
\hline & $(0.85)$ & $(0.90)$ \\
\hline \multirow[t]{2}{*}{ Multinationals } & -1.35 & -6.11 \\
\hline & $(4.79)$ & $(6.55)$ \\
\hline \multirow[t]{2}{*}{ Technological Disruption Period } & $-4.15^{* *}$ & $-6.70 * * *$ \\
\hline & $(1.93)$ & $(2.53)$ \\
\hline \multirow[t]{2}{*}{ Economic Disruption Period } & $-6.14 * * *$ & $-6.32 * * *$ \\
\hline & $(1.95)$ & $(2.40)$ \\
\hline Technological & & $7.43^{* *}$ \\
\hline Disruption*Multinationals & & $(3.45)$ \\
\hline \multirow[t]{2}{*}{ Economic Disruption*Multinationals } & & 0.35 \\
\hline & & $(3.76)$ \\
\hline \multirow[t]{2}{*}{ Cons } & $-42.20 * * *$ & $-45.34 * * *$ \\
\hline & $(10.43)$ & $(10.80)$ \\
\hline Number of obs. & 158 & 158 \\
\hline Number of firms & 9 & 9 \\
\hline Overall $R^{2}$ & 0.15 & 0.17 \\
\hline Between $R^{2}$ & 0.16 & 0.17 \\
\hline
\end{tabular}

Estimation performed with Random Effects and Huber-White robust standard errors, which are reported within parenthesis. Level of statistical significance: *** 1\%,**5\%,*10\%. 
Figure 1. Return on Assets evolution of the global business of multinational music firms

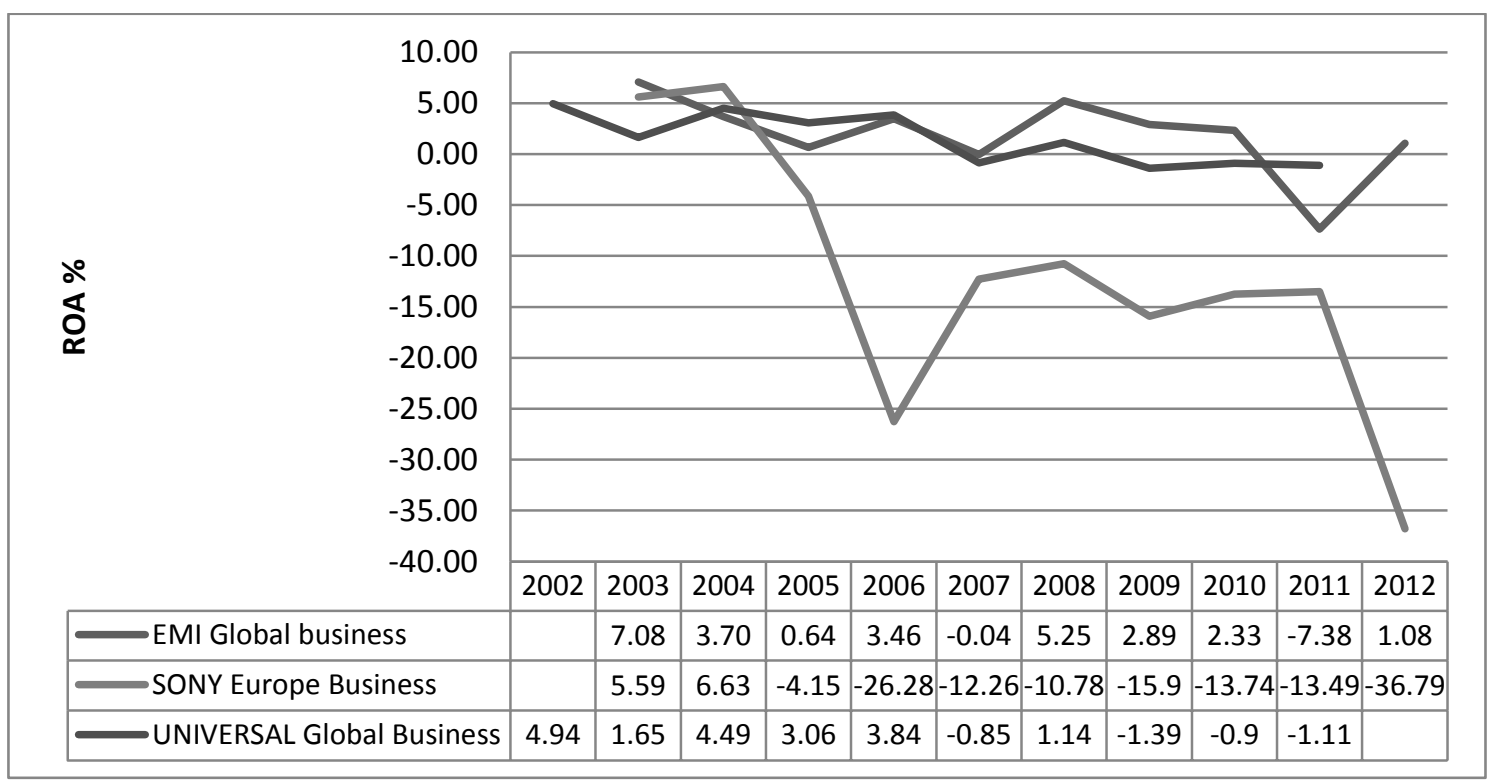

Figure 2. Return on Assets evolution of the multinational music firms operating in Spain

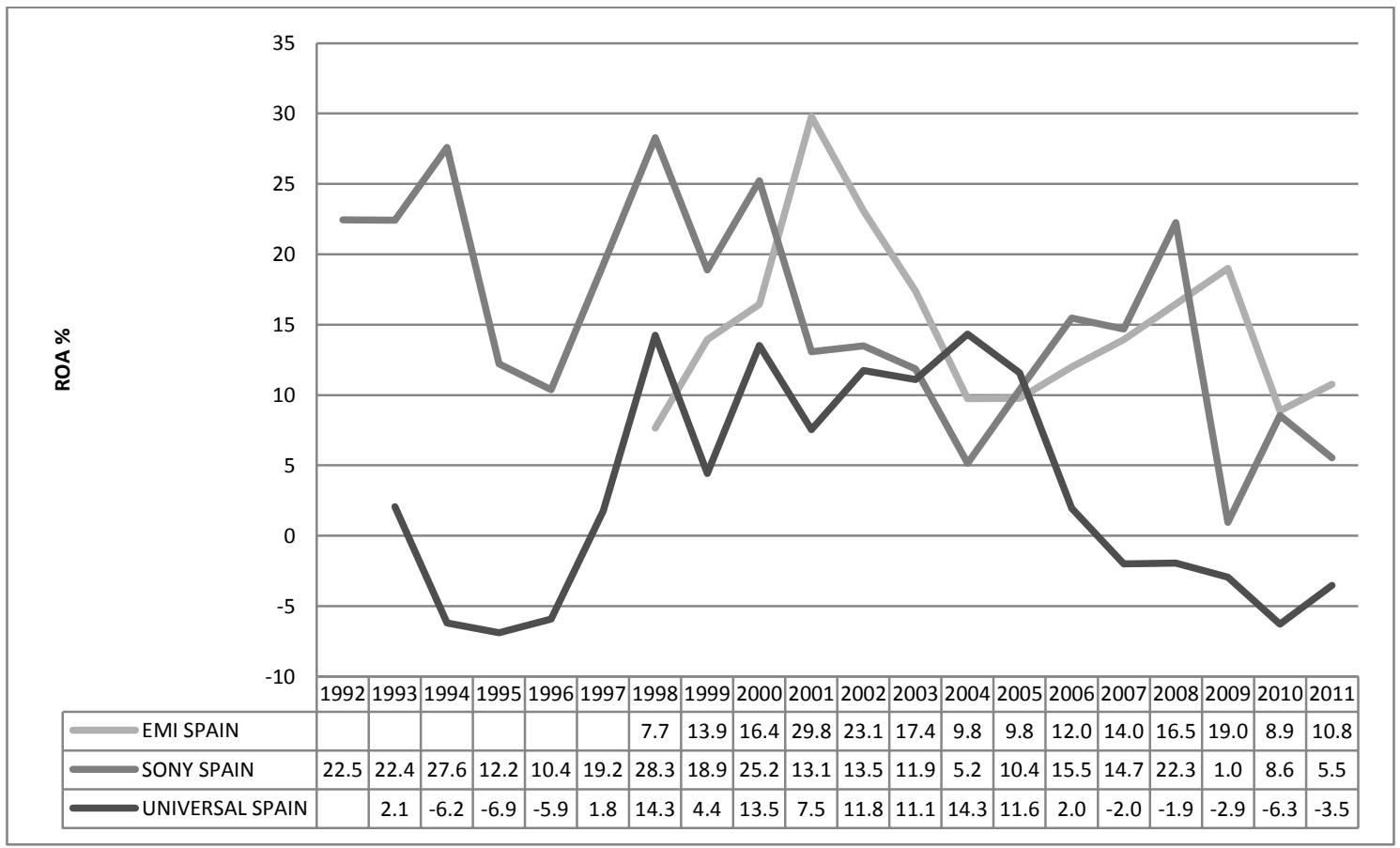


Figure 3. Return on Assets evolution for Spanish local music firms

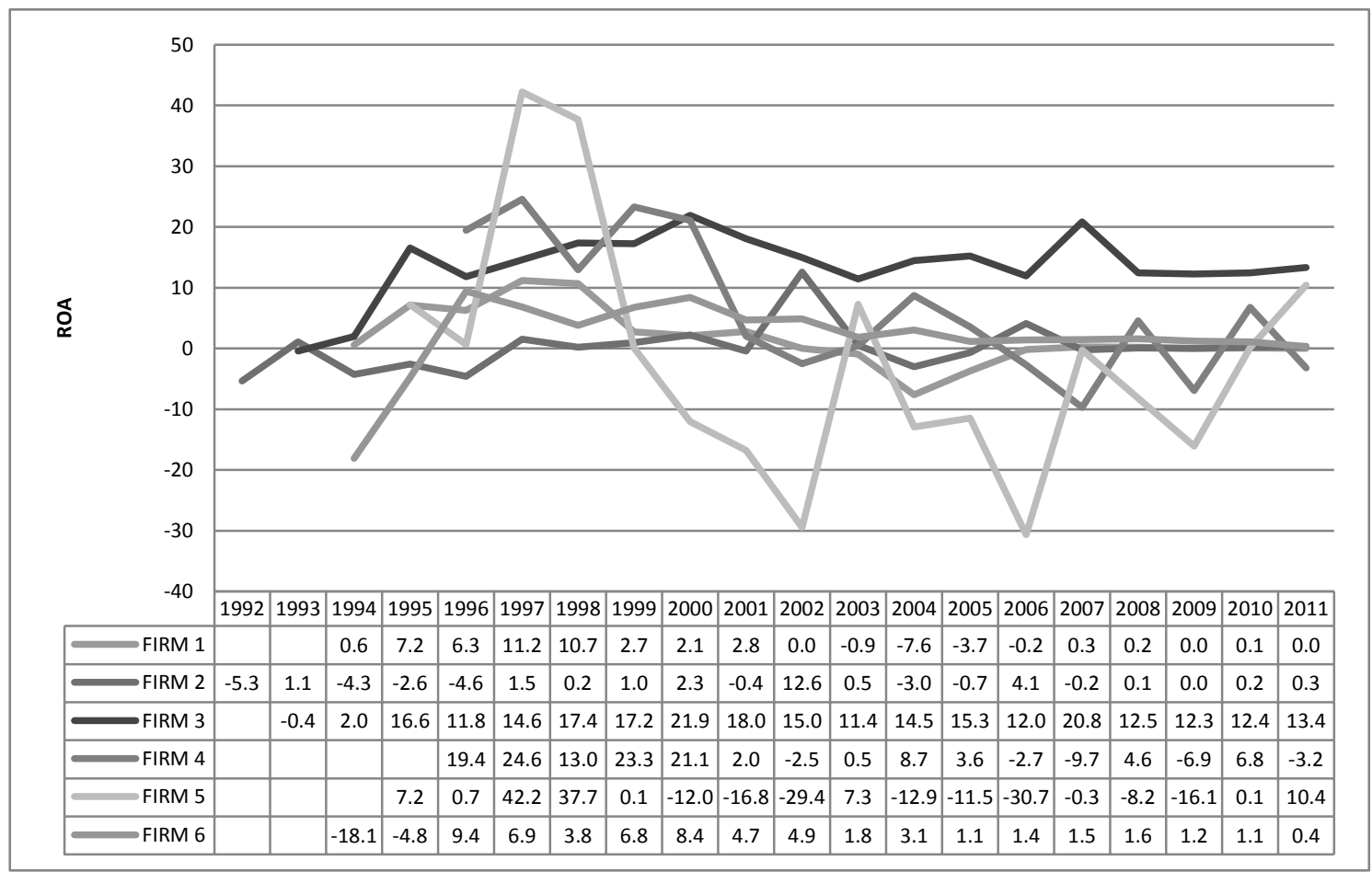

